\title{
Profiling the Expression of Circulating Acute-Phase Proteins, Cytokines, and Checkpoint Proteins in Patients with Severe Trauma: A Pilot Study
}

\author{
Shao-Chun Wu (iD) ${ }^{1, *}$ \\ Cheng-Shyuan $\operatorname{Rau}^{2, *}$ \\ Pao-Jen Kuo ${ }^{3}$ \\ Fu-Yuan Shih ${ }^{2}$ \\ Hui-Ping Lin ${ }^{3}$ \\ Yi-Chan $\mathrm{Wu}^{3}$ \\ Ting-Min Hsieh ${ }^{4}$ \\ Hang-Tsung Liu ${ }^{4}$ \\ Ching-Hua Hsieh (D) ${ }^{3}$ \\ 'Department of Anesthesiology, \\ Kaohsiung Chang Gung Memorial \\ Hospital and Chang Gung University \\ College of Medicine, Kaohsiung, Taiwan; \\ ${ }^{2}$ Department of Neurosurgery, \\ Kaohsiung Chang Gung Memorial \\ Hospital and Chang Gung University \\ College of Medicine, Kaohsiung, Taiwan; \\ ${ }^{3}$ Department of Plastic Surgery, \\ Kaohsiung Chang Gung Memorial \\ Hospital and Chang Gung University \\ College of Medicine, Kaohsiung, Taiwan; \\ ${ }^{4}$ Department of Trauma Surgery, \\ Kaohsiung Chang Gung Memorial \\ Hospital and Chang Gung University \\ College of Medicine, Kaohsiung, Taiwan
}

*These authors contributed equally to this work
Correspondence: Ching-Hua Hsieh

Department of Plastic Surgery, Kaohsiung

Chang Gung Memorial Hospital and Chang

Gung University College of Medicine,

No. 123, Ta-Pei Road, Niao-Song District,

Kaohsiung, 833, Taiwan

Tel +886-7-7327476

Fax +886-7-3450431

Email m93chinghua@gmail.com
Purpose: Severe trauma may lead to the systemic release of inflammatory mediators into the circulation with profound acute-phase responses; however, the understanding of the expression of these mediators remains limited. This study aimed to characterize the alterations in the expression of circulating acute-phase proteins, cytokines, and checkpoint proteins in patients with severe trauma injuries.

Patients and Methods: The study population included trauma patients in the intensive care unit (ICU) with an injury severity score equal to or greater than 16 and who had used a ventilator for 48 hours. A total of 12 female and 28 male patients were recruited for the study; six patients died and 34 survived. Blood samples collected at acute stages were compared with those drawn at the subacute stage, the time when the patients were discharged from the ICU, or before the discharge of the patients from the hospital.

Results: The study identified that the expression of acute-phase proteins, such as alpha1 -acid glycoprotein and C-reactive protein, and cytokines, including granulocyte colonystimulating factor, interleukin-6, and interleukin-1 receptor antagonist, was elevated in the circulation after severe trauma. In contrast, the levels of acute-phase proteins, such as alpha2-macroglobulin, serum amyloid $\mathrm{P}$, and von Willebrand factor, and cytokines, including interleukin-4 and interferon gamma-induced protein 10, were reduced. However, there were no significant differences in the expression of checkpoint proteins in the circulation.

Conclusion: The dysregulated proteins identified in this study may serve as potential therapeutic targets or biomarkers for treating patients with severe trauma. However, the related biological functions of these dysregulated factors require further investigation to validate their functions.

Keywords: circulation, inflammatory reaction, biomarkers, severe trauma, critical illness

\section{Introduction}

Tissue damage during trauma results in the release of damage-associated molecular patterns and other mediators at the site of injury. Such mediators disrupt the homeostasis of the immune system and may activate various immune responses with downstream complications, such as infections and sepsis. To adapt and survive, hosts react with a set of mechanisms aimed at restoring the equilibrium of the immune system. The acute phase response of the innate immune system plays a crucial role in trauma ${ }^{1}$ and is demonstrated by the change in circulating acute-phase protein levels; this may explain the differences in susceptibility to infectious organisms. ${ }^{2}$ The systemic acute phase response might impair host 
defense against $P$. aeruginosa pneumonia ${ }^{3}$ and inhibit the local inflammatory response to A. baumannii pneumonia, thereby facilitating the outgrowth of bacteria. ${ }^{4}$

Trauma leads to the systemic release of inflammatory mediators into the circulation from norepinephrine terminals in peripheral organs such as the liver, spleen, and lymphocytes. ${ }^{5,6}$ These cytokines from severely injured trauma patients systemically regulate cytokine expression in the bone marrow stroma, ${ }^{7}$ resulting in the prolonged mobilization of hematopoietic progenitor cells from the bone marrow stroma ${ }^{8}$ into the circulation and to the site of injury. ${ }^{9-11}$ These cytokines are involved in the early systemic inflammatory response as well as in the compensatory anti-inflammatory response that occurs later. An imbalance in these responses is responsible for the development of sepsis or multiple organ failure. ${ }^{12,13}$ In addition to the participation of these cytokines in inflammatory processes, they are also the chief stimulators of acutephase proteins. ${ }^{14}$

The balance of the immune system is controlled by checkpoint regulators in the body. The checkpoint regulators are membrane-bound proteins that serve as a secondary signal to direct the immune response to a particular antigen. ${ }^{15}$ In the absence of such signals, the immune response is neither activated nor attenuated. ${ }^{15}$ After the modification of the immune response over time, these checkpoint regulators enable the unique response of immune cells to various environmental conditions. ${ }^{16}$ For example, after burn injury, anti-programmed cell death ligand-1 (anti-PD-L1) effectively increases bacterial clearance, protects against multiple organ failure, and improves survival following systemic $S$. aureus infection. ${ }^{17}$ In addition, activation of the PD-1/PD-L1 pathway with PD-L1 protein significantly attenuates inflammatory responses and brain edema in the treatment of surgical brain injury. ${ }^{18,19}$

Although patients who succumb to severe injuries are known to have profoundly different inflammatory and acute-phase responses, the understanding of these processes remains limited. ${ }^{20}$ There is also a lack of information on the expression of immune checkpoint proteins following severe traumatic injury. Cytokines and cytokine receptors operate together with the produced acute-phase proteins in a cascade effect to influence the pathophysiological response of the body following trauma. ${ }^{1}$ Therefore, the characterization of these proteins may help in the identification of therapeutic targets or biomarkers for patients with severe trauma. Accordingly, the present study aimed to characterize the alterations in the expression of circulating acute-phase proteins, cytokines, and checkpoint proteins in patients who experienced severe trauma.

\section{Patients and Methods}

\section{Patients Enrollment}

Only patients who satisfied the following three conditions were included in this study: (1) adult trauma patients aged 20 years and above who were admitted to the trauma ICU, (2) patients with an injury severity score (ISS) equal to or greater than 16 , indicating severe injury, ${ }^{21-23}$ and (3) the use of ventilator support for more than $48 \mathrm{~h}$. Exclusion criteria included patients with cancer, those who were immunocompromised, or were not willing to be involved in this study. Finally, 40 critical adult trauma patients admitted to the hospital between December 2017 and December 2018 were enrolled in this study. This prospective study was approved by the institutional review board of the hospital. All patients signed a written consent before blood sample collection.

\section{Clinical Data and Specimen Collection}

The medical information of patients was collected from the Trauma Registry System of the hospital ${ }^{2-26}$ and included sex, age, pre-existing comorbidities, abbreviated injury scale (AIS) in different body regions, ISS, period of ventilator use, and final condition (mortality or survival). From the medical charts, the vital signs, including temperature, systolic blood pressure (SBP), heart rate (HR), and respiratory rate $(\mathrm{RR})$ at the time of blood collection were recorded with the laboratory data, including white blood cell (WBC) and platelet counts, and hematocrit (Hct), sodium $(\mathrm{Na})$, potassium $(\mathrm{K})$, blood urine nitrogen (BUN), creatinine (Cr), aspartate aminotransferase (AST), and bilirubin levels. The Revised Trauma Score (RTS) was calculated by taking the weighted sum of $0.9368 \times$ Glasgow Coma Scale (GCS) score $+0.7326 \times$ SBP + $0.2908 \times \mathrm{RR}^{27}$ The trauma and injury severity score (TRISS) was calculated based on a logarithmic regression equation: survival probability $=1 /(1+\mathrm{e}-\mathrm{b})$, where $\mathrm{b}$ (penetrating injury) $=-2.5355+0.9934 \times$ RTS $0.0651 \times$ ISS $-1.1360 \times$ Age(index) and b (blunt injury) $=-0.4499+0.8085 \times$ RTS $-0.0835 \times$ ISS $-1.7430 \times$ Age(index). In the formula, age (index) is awarded 1, where patients above 55 and patients below and of 55 are awarded $0 .{ }^{27}$ When the patients were admitted to the 
trauma ICU and had used a ventilator for $48 \mathrm{~h}$, peripheral blood samples were collected prospectively after this time point but within $72 \mathrm{~h}$ after admission into the ICU. The blood samples drawn at this time point are indicated as acute-stage samples. Another peripheral blood sample from the same patient population was drawn from the patients in the ward just before discharge from the hospital, after they had left the ICU. The blood samples drawn at this time point are indicated as subacute-stage samples. A second blood sample was not drawn from patients who died in the ICU. Ten $\mathrm{mL}$ of the fasting blood was drawn from the veins of the forearm. Serum was obtained from peripheral blood samples using Becton Dickinson Serum Separator Tubes (BD Vacutainer ${ }^{\circledR}$ SST $^{\text {TM }}$ Tube, BD Diagnostics, Franklin Lakes, NJ) with no additives, centrifuged, collected, aliquoted, and immediately frozen at $-80{ }^{\circ} \mathrm{C}$ until use.

\section{Multiplex Enzyme-Linked Immunosorbent Assay (ELISA)}

Serum protein expression was measured using the Multiplex platform (Luminex system, Millipore, MA) for ELISA with panels of human acute-phase proteins (human cardiovascular panel 3, Cat. No. HCVD3MAG-67K), human cytokines, and chemokines (human cytokine/chemokine panel I, Cat. No. HCYTOMAG-60K), and human checkpoint protein (human immune checkpoint protein, Cat. No. HCKPMAG-11K) in duplicate for each patient sample, according to the manufacturer's protocol. The inter- and intra-assay percentages of the coefficients of variability $(\% \mathrm{CV})$ are listed in Supplemental Table 1.

The acute-phase proteins included alpha-2-macroglobulin (A2M), alpha-1-acid glycoprotein (AGP), adipsin/ factor D, C-reactive protein (CRP), fetuin-A, fibrinogen, haptoglobin, sL-selectin, platelet factor 4 (PF4), serum amyloid P (SAP), and von Willebrand factor (vWF). The concentration of serum proteins was expressed in $\mathrm{pg} / \mathrm{mL}$.

The cytokines and chemokines included soluble CD40 ligand (sCD40L), epidermal growth factor (EGF), eotaxin, fibroblast growth factor 2 (FGF-2), FMS-like tyrosine kinase 3 (FLT3) ligand, fractalkine, granulocyte colonystimulating factor (G-CSF), granulocyte-macrophage colony-stimulating factor (GM-CSF), growth-related oncogene (GRO), interferon $\alpha 2$ (IFN- $\alpha 2), \operatorname{IFN} \gamma$, interleukin (IL)-1 $\alpha$, IL-1 $\beta$, IL-1RA, IL-2, IL-3, IL-4, IL-5, IL-6, IL7, IL-8, IL-9, IL-10, IL-12 (p40), IL-12 (p70), IL-13, IL-
15, IL-17A, interferon gamma-induced protein 10 (IP-10), monocyte chemotactic protein 1 (MCP-1), MCP-3, macrophage-derived chemokine (MDC), macrophage inflammatory protein $1 \alpha(\mathrm{MIP}-1 \alpha)$, MIP-1 $\beta$, platelet-derived growth factor (PDGF)-AA, PDGF-AB/BB, RANTES, tumor necrosis factor $\alpha$ (TNF- $\alpha)$, TNF- $\beta$, and vascular endothelial growth factor (VEGF)-A.

The checkpoint proteins include B- and T-lymphocyte attenuator (BTLA), cluster of differentiation (CD)27, CD28, CD40, CD80, CD86, cytotoxic T-lymphocyte antigen 4 (CTLA-4), glucocorticoid-induced TNFR-related protein (GITR), glucocorticoid-induced TNFR-related protein ligand (GITRL), herpes virus entry mediator (HVEM), inducible T-cell co-stimulator (ICOS), lymphocyte-activation protein 3 (LAG-3), programmed cell death 1 (PD-1), programmed cell death ligand 1 (PD-L1), T-cell immunoglobulin and mucindomain containing-3 (TIM-3), and Toll-like receptor 2 (TLR2).

\section{Statistical Analysis}

Data were analyzed using Windows version 23.0 (IBM Inc., Chicago, IL, USA). Two-sided Fisher's exact or Pearson's chi-squared $(\chi 2)$ tests were used to compare categorical data. Continuous data were analyzed using the non-parametric Mann-Whitney U-test. Pearson's correlation coefficient analysis was carried out to measure the correlation between patient characteristics and differentially expressed protein targets at the acute and subacute stages. Continuous data are expressed as the median and interquartile range (IQR, Q1-Q3). Statistical significance was indicated by two-sided $\mathrm{p}$ values $<0.05$.

\section{Results}

\section{Patient Characteristics}

The enrolled patients included 12 female and 28 male patients with an average age of $56.3 \pm 18.4$ years (mini-max 22-84 years). During the study, six patients died, and 34 survived. For surviving patients, the time between the first (acute stage) and second (subacute stage) blood sample collection was 21.1 \pm 8.9 days. As shown in Table 1 , there were no significant differences in the age and prevalence of sex or pre-existing comorbidities between the survival and death groups. In these two groups, there were no significant differences in vital signs and laboratory data. No significant difference was also found between the death and survival of patients with AIS in different body regions, ISS, RTS, or TRISS. 
Table I Characteristics of Patients in the Survival and Death Groups

\begin{tabular}{|c|c|c|c|}
\hline Variables & Survival $n=34$ & Death $n=6$ & P-value \\
\hline Age (years) & $56.5[37.5,65.5]$ & $68.0[59.8,80.0]$ & 0.072 \\
\hline \multicolumn{4}{|l|}{ Gender } \\
\hline Male, n (\%) & $24(70.6)$ & $4(66.7)$ & $>0.999$ \\
\hline Female, n (\%) & $10(29.4)$ & $2(33.3)$ & \\
\hline \multicolumn{4}{|l|}{ Co-morbidities } \\
\hline DM, n (\%) & $6(17.6)$ & $0(0.0)$ & 0.565 \\
\hline HTN, n (\%) & $9(26.5)$ & $4(66.7)$ & 0.075 \\
\hline CAD, n (\%) & $3(8.8)$ & I (I6.7) & 0.493 \\
\hline CVA, n (\%) & I (2.9) & I (I6.7) & $0.28 \mathrm{I}$ \\
\hline AIS (head/neck) & & & 0.835 \\
\hline 0 & $6(17.6)$ & I (I6.7) & \\
\hline 2 & $2(5.9)$ & $0(0.0)$ & \\
\hline 3 & $2(5.9)$ & $0(0.0)$ & \\
\hline 4 & 14 (4I.2) & $2(33.3)$ & \\
\hline 5 & $10(29.4)$ & $3(50.0)$ & \\
\hline AIS (face) & & & 0.473 \\
\hline 0 & $27(79.4)$ & $6(100.0)$ & \\
\hline 1 & I (2.9) & $0(0.0)$ & \\
\hline 2 & $6(17.6)$ & $0(0.0)$ & \\
\hline AIS (thorax) & & & 0.867 \\
\hline 0 & $23(67.6)$ & $4(66.7)$ & \\
\hline 1 & I (2.9) & $0(0.0)$ & \\
\hline 3 & $8(23.5)$ & $2(33.3)$ & \\
\hline 4 & $2(5.9)$ & $0(0.0)$ & \\
\hline AIS (abdomen) & & & 0.623 \\
\hline 0 & $26(76.5)$ & $6(100.0)$ & \\
\hline 3 & $2(5.9)$ & $0(0.0)$ & \\
\hline 4 & $4(11.8)$ & $0(0.0)$ & \\
\hline 5 & $2(5.9)$ & $0(0.0)$ & \\
\hline AIS (extremity) & & & 0.779 \\
\hline 0 & $20(58.8)$ & $5(83.3)$ & \\
\hline 1 & I (2.9) & $0(0.0)$ & \\
\hline 2 & $7(20.6)$ & I (I6.7) & \\
\hline 3 & $5(14.7)$ & $0(0.0)$ & \\
\hline 4 & I (2.9) & $0(0.0)$ & \\
\hline Temperature $\left({ }^{\circ} \mathrm{C}\right)$ & $36.5[36.0,37.3]$ & $36.6[36.0,37.3]$ & 0.594 \\
\hline SBP (mmHg) & $142.0[1 \mid 2.8,163.8]$ & $140.0[106.5,152.5]$ & 0.691 \\
\hline Heart rate (times/min) & $93.5[75.0,112.5]$ & $86.0[85.0,117.8]$ & 0.955 \\
\hline Respiratory rate (times/min) & $20.0[18.0,21.8]$ & $19.0[18.0,23.0]$ & 0.893 \\
\hline WBC $\left(10^{3} / \mathrm{uL}\right)$ & $11.9[9.7,14.6]$ & $10.3[8.9,14.3]$ & 0.677 \\
\hline Hct (\%) & $41.1[37.3,44.7]$ & $40.8[37.3,43.9]$ & 0.910 \\
\hline Platelet $\left(10^{3} / \mathrm{uL}\right)$ & $208.0[189.5,232.5]$ & $206.0[174.8,256.8]$ & 0.850 \\
\hline $\mathrm{Na}(\mathrm{mEq} / \mathrm{L})$ & $138.0[135.3,139.8]$ & I37.5 [135.3, 139.8] & 0.717 \\
\hline
\end{tabular}

(Continued) 
Table I (Continued).

\begin{tabular}{|l|c|c|c|}
\hline Variables & Survival $\mathbf{n}=\mathbf{3 4}$ & Death $\mathbf{n}=\mathbf{6}$ & P-value \\
\hline K $(\mathrm{mEq} / \mathrm{L})$ & $3.7[3.2,3.9]$ & $3.1[2.7,3.6]$ & 0.119 \\
\hline BUN $(\mathrm{mg} / \mathrm{dL})$ & $16.0[12.0,19.8]$ & $17.5[15.3,22.0]$ & 0.426 \\
\hline Cr $(\mathrm{mg} / \mathrm{dL})$ & $0.9[0.8,1.3]$ & $1.0[0.9,1.2]$ & 0.705 \\
\hline AST & $44.5[32.0,95.5]$ & $66.0[49.5,138.0]$ & 0.272 \\
\hline Bilirubin $(\mathrm{mg} / \mathrm{dL})$ & $0.9[0.6,1.0]$ & $1.1[0.9,1.3]$ & 0.164 \\
\hline ISS & $24.5[18.5,25.0]$ & $20.5[16.0,31.8]$ & 0.552 \\
\hline RTS & $6.6[5.8,7.4]$ & $5.5[5.1,6.3]$ & 0.258 \\
\hline TRISS & $0.85[0.64,0.95]$ & $0.83[0.40,0.88]$ & 0.437 \\
\hline
\end{tabular}

Note: The data are expressed as $\mathrm{n}(\%)$ or median with IQR [QI-Q3].

Abbreviations: AIS, Abbreviated Injury Scale; AST, aspartate aminotransferase; BUN, blood urea nitrogen; CAD, coronary artery disease; Cl, confidence interval; CVA, cerebral vascular accident; DM, diabetes mellitus; Hct, hematocrit; HTN, hypertension; IQR, interquartile range; ISS, injury severity score; K, potassium; Na, sodium; RTS, Revised Trauma Score; TRISS, New Trauma and Injury Severity Score; WBC, white blood cells.

\section{Expression of the Acute Phase Proteins}

There was no significant difference in the acute-phase proteins of acute-stage serum samples between survival $(n=34)$ and death $(\mathrm{n}=6)$. The acute-stage serum concentrations of AGP $(P=0.001)$ and CRP $(P<0.001)$ were significantly higher than those in the subacute-stage serum (Table 2 and Figure 1). The elevation of CRP in the acute stage of either survival or even death was approximately 3 -fold higher than that in the subacute stage. Conversely, the acute-stage serum concentrations of A2M $(P=0.002)$, SAP $(P=0.006)$, and vWF $(P=0.018)$ in the surviving patients $(\mathrm{n}=34)$ were significantly lower than those in the subacute-stage serum.

\section{Expression of the Cytokines and Chemokines}

The acute-stage serum concentrations of G-CSF and IL-6 in the patients who died were significantly higher than those in the acute-stage serum of the surviving patients (Table 3 and Figure 2). Among patients who died, the elevation of G-CSF and IL-6 in the acute stage was 5-fold $(P=0.008)$ and 6-fold $(P=0.013)$, respectively, compared to those of the surviving patients. The acute-stage serum concentrations of G-CSF and IL-6 in surviving patients were 3-fold $(P=0.014)$ and 6-fold $(P<0.001)$ higher, respectively, than those in the subacute stage. The acute-stage serum concentrations of IL-1RA $(P=$

Table 2 Expression of the Acute Phase Proteins in the Acute-Stage and Subacute-Stage Serum Samples

\begin{tabular}{|c|c|c|c|c|c|}
\hline \multirow[t]{2}{*}{ Variables } & \multicolumn{2}{|l|}{ Acute Stage } & \multirow{2}{*}{$\begin{array}{l}\text { Subacute Stage } \\
\text { Survival } n=34\end{array}$} & \multirow[t]{2}{*}{ \#I P } & \multirow[t]{2}{*}{ \#2 P } \\
\hline & Survival $n=34$ & Death $n=6$ & & & \\
\hline$A 2 M$ & $82 I, 565(279,98 I)$ & $I, 050,820(37 I, 744)$ & $993,596(254,318)$ & 0.099 & 0.002 \\
\hline Adipsin & $5270(5735)$ & $5138(2306)$ & $5107(5749)$ & 0.256 & 0.213 \\
\hline AGP & $2,8|0,2| 3(I, \mid 75,978)$ & $2,897,929(1,224,919)$ & $2,054,879(626,089)$ & 0.895 & 0.001 \\
\hline CRP & $360,253(146,016)$ & $378,844(192,584)$ & $124,470(127,898)$ & 0.636 & $<0.001$ \\
\hline CXCL4 & $1000(167 \mid)$ & $969(1130)$ & $1248(|79|)$ & 0.647 & 0.236 \\
\hline Fetuin A & I48,099 (85,979) & $123,914(19,340)$ & $\mid 33,187(69,34 \mid)$ & 0.925 & 0.504 \\
\hline Fibrinogen & $594,995(243,066)$ & $601,345(69,059)$ & $539,928(154,057)$ & 0.609 & 0.094 \\
\hline Haptoglobin & I,4I7,I50 (985,468) & $1,988,356(662,764)$ & $\mathrm{I}, 360, \mathrm{I} \mid \mathrm{I}(\mathrm{I}, \mathrm{I74,957)}$ & 0.175 & 0.559 \\
\hline sL-Selectin & $572(256)$ & $557(124)$ & $683(239)$ & 0.583 & 0.062 \\
\hline SAP & 11,969 (6243) & 110,010 (4965) & 15,628 (7458) & 0.895 & 0.006 \\
\hline vWF & $21,46 \mid(12,118)$ & $24,547(16,434)$ & $31,892(21,588)$ & 0.691 & 0.018 \\
\hline
\end{tabular}

Notes: \#I, comparison between surviving and dead patients in the acute stage; \#2, comparison between surviving patients in the acute and subacute stages. The concentration of serum proteins is expressed in $\mathrm{pg} / \mathrm{mL}$.

Abbreviations: A2M, $\alpha$-2-Macroglobulin; AGP, $\alpha$-I-Acid glycoprotein; CRP, C-reactive protein. 


\section{Up-regulation}

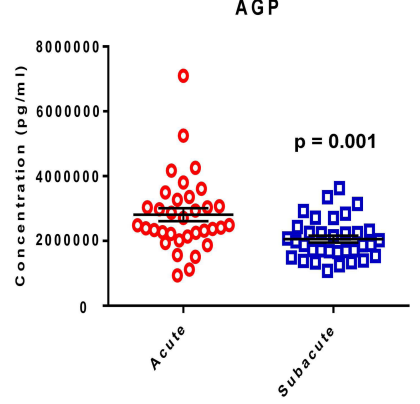

G-CSF

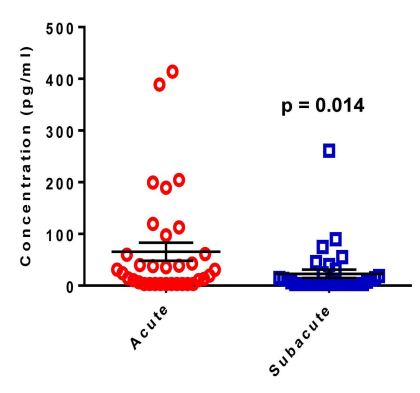

Down-regulation

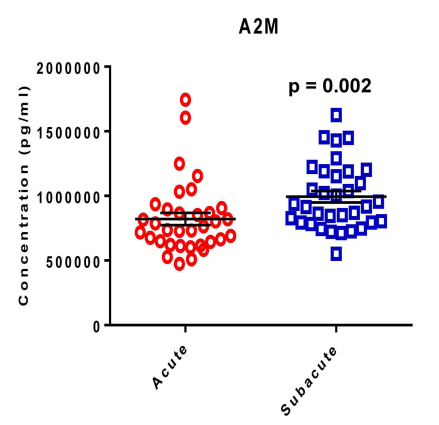

IL-4

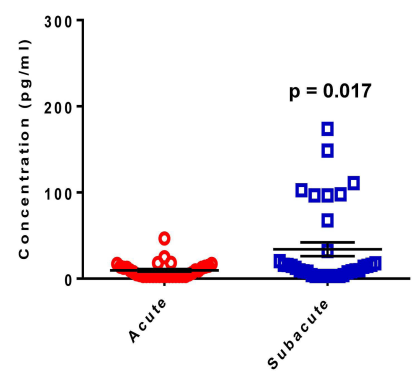

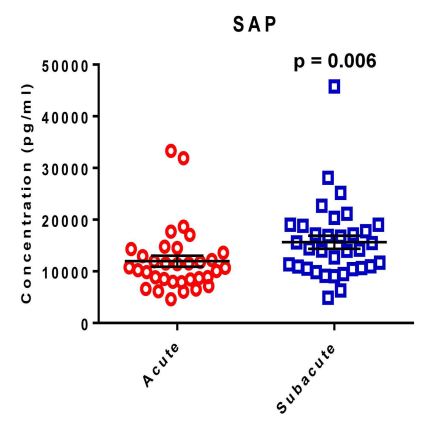
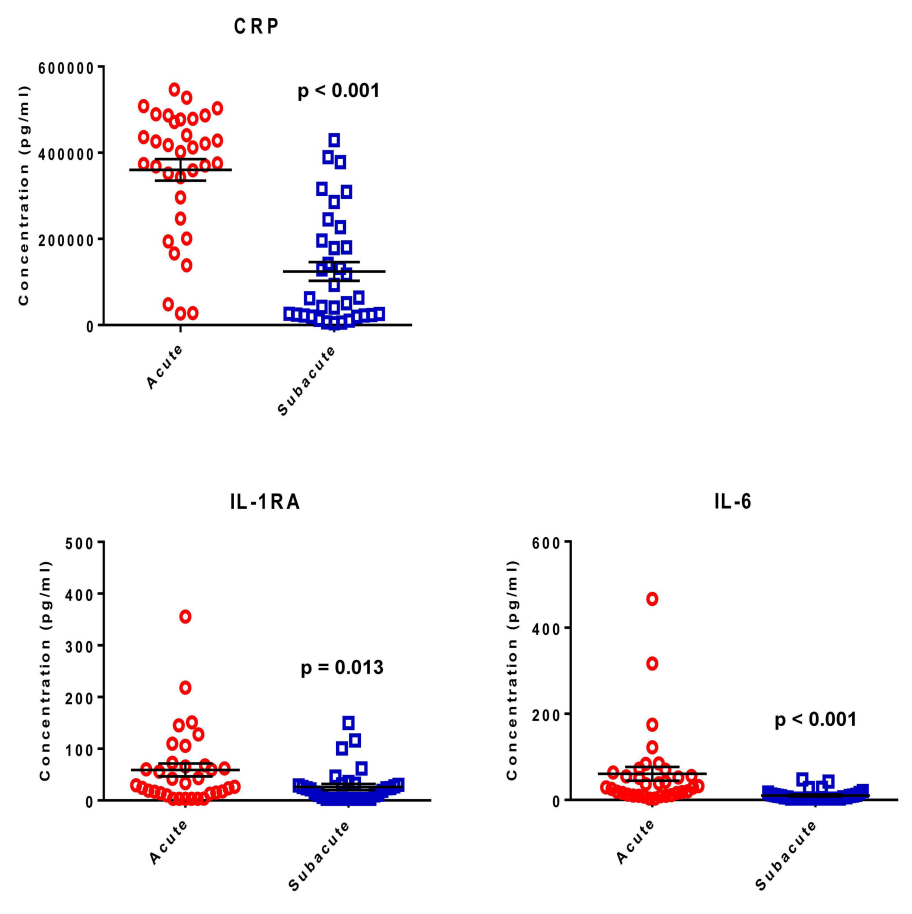

IL-1RA

vW F

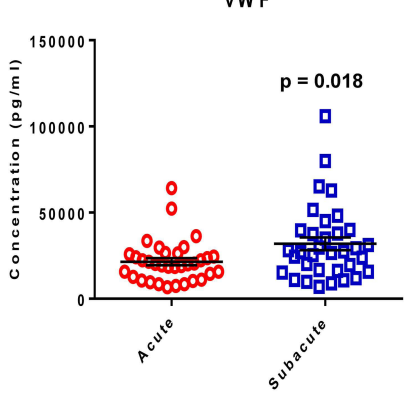

IP -10

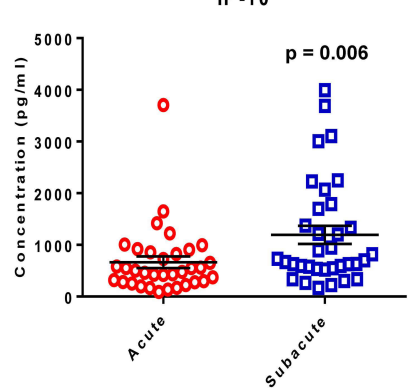

Figure I Circulating acute-phase proteins and cytokines with significantly different expression in the acute-stage and subacute-stage serum samples of the surviving patients.

0.013) were significantly higher than those in the subacutestage serum. In contrast, the acute-stage serum concentrations of IL-4 $(P=0.017)$ and IP-10 $(P=0.006)$ were significantly lower than those in the subacute-stage serum (Table 3 and Figure 1).

\section{Expression of the Checkpoint Proteins}

There were no significant differences in the checkpoint proteins in the acute-stage serum samples between patients who survived and those who died. In addition, there were no significant differences in serum checkpoint 
Table 3 Expression of the Cytokines and Chemokines in the Acute-Stage and Subacute-Stage Serum Samples

\begin{tabular}{|c|c|c|c|c|c|}
\hline \multirow[t]{2}{*}{ Variables } & \multicolumn{2}{|l|}{ Acute Stage } & \multirow{2}{*}{$\begin{array}{l}\text { Subacute Stage } \\
\text { Survival } n=34\end{array}$} & \multirow[t]{2}{*}{ \#I P } & \multirow[t]{2}{*}{ \#2 P } \\
\hline & Survival $n=34$ & Death $n=6$ & & & \\
\hline EGF & 6.88 (8.99) & 4.11 (2.22) & I I.49 (2I.73) & 0.679 & 0.522 \\
\hline Eotaxin & 66.31 (36.88) & $57.66(10.04)$ & 73.25 (5I.68) & 0.925 & 0.615 \\
\hline FGF-2 & $61.20(50.32)$ & $53.48(29.47)$ & $57.22(47.32)$ & 0.880 & 0.883 \\
\hline Flt3 Ligand & $9.02(19.59)$ & $3.20(0.00)$ & II.90 (25.34) & 0.072 & 0.714 \\
\hline Fractalkine & 71.92 (285.23) & $34.32(24.05)$ & $58.23(206.74)$ & 0.149 & 0.487 \\
\hline G-CSF & $65.63(102.74)$ & 311.67 (268.99) & $22.85(47.31)$ & 0.008 & 0.014 \\
\hline GM-CSF & $6.65(4.30)$ & 7.01 (4.33) & $8.34(8.16)$ & 0.789 & 0.656 \\
\hline GRO & $253.50(255.26)$ & $210.90(158.34)$ & $404.26(360.27)$ & 0.748 & 0.138 \\
\hline IFN $\alpha 2$ & I5.0| (23.5I) & I7.67 (II.34) & I5.85 (I3.70) & 0.227 & 0.127 \\
\hline $\mathrm{IFN} \gamma$ & $14.05(14.25)$ & $6.11(2.84)$ & 15.79 (20.67) & 0.280 & 0.615 \\
\hline IL-IRA & $64.82(100.69)$ & $120.42(\mid 25.44)$ & $26.14(34.11)$ & 0.218 & 0.013 \\
\hline IL-I $\alpha$ & $16.08(20.31)$ & $19.16(24.18)$ & 41.79 (8I.35) & 0.875 & 0.077 \\
\hline IL-I $\beta$ & $3.83(3.66)$ & 3.64 (1.08) & $4.96(5.96)$ & 0.561 & 0.152 \\
\hline IL-2 & $3.69(1.73)$ & $3.20(0.00)$ & $4.40(4.83)$ & 0.081 & 0.544 \\
\hline IL-3 & $3.26(0.33)$ & $3.20(0.00)$ & $3.20(0.00)$ & 0.057 & 0.167 \\
\hline IL-4 & 9.55 (8.91) & 8.54 (4.29) & 34.15 (46.77) & 0.922 & 0.017 \\
\hline IL-5 & $3.47(1.13)$ & 3.71 (1.24) & $3.49(1.17)$ & 0.717 & 0.762 \\
\hline IL-6 & $63.79(107.17)$ & 380.26 (782.47) & $10.29(11.22)$ & 0.013 & $<0.001$ \\
\hline IL-7 & $6.76(12.70)$ & $4.05(2.01)$ & $5.76(14.08)$ & 0.407 & 0.654 \\
\hline IL-8 & 9.31 (12.09) & II.75 (14.0I) & $5.38(3.55)$ & 0.772 & 0.054 \\
\hline IL-9 & $3.20(0.00)$ & $3.20(0.00)$ & $3.15(0.29)$ & 0.176 & 1.000 \\
\hline IL-10 & $28.23(62.96)$ & $28.78(29.44)$ & $18.82(51.26)$ & 0.894 & 0.051 \\
\hline IL-I2 (p40) & $3.92(2.49)$ & 4.31 (2.7I) & $7.83(17.12)$ & 0.855 & 0.495 \\
\hline IL-I2 (p70) & $7.58(15.97)$ & $3.83(0.99)$ & $8.10(23.93)$ & 0.455 & 0.230 \\
\hline IL-13 & $3.38(0.68)$ & $4.31(2.72)$ & $6.56(11.87)$ & 0.513 & 0.921 \\
\hline IL-I5 & $4.97(1.86)$ & $4.28(1.58)$ & $3.78(1.48)$ & 0.471 & 0.352 \\
\hline IL-I7A & $10.88(11.17)$ & $3.83(1.37)$ & 9.35 (11.29) & 0.249 & 0.202 \\
\hline IP-I0 & $665.43(654.66)$ & $837.46(883.24)$ & $1194.04(1016.73)$ & 0.925 & 0.006 \\
\hline MCP-I & $606.00(857.73)$ & $1287.40(2 \mid 69.67)$ & 358.61 (296.53) & 0.748 & 0.069 \\
\hline MCP-3 & $7.72(8.44)$ & $5.56(3.59)$ & 10.35 (23.09) & 0.516 & 0.478 \\
\hline MDC & 293.65 (131.59) & 251.75 (168.99) & $390.28(326.88)$ & 0.507 & 0.150 \\
\hline MIP-I $\alpha$ & $4.80(3.08)$ & $5.67(3.95)$ & $4.95(3.4 I)$ & 0.486 & 1.000 \\
\hline
\end{tabular}


Table 3 (Continued).

\begin{tabular}{|c|c|c|c|c|c|}
\hline \multirow[t]{2}{*}{ Variables } & \multicolumn{2}{|l|}{ Acute Stage } & \multirow{2}{*}{$\begin{array}{l}\text { Subacute Stage } \\
\text { Survival } n=34\end{array}$} & \multirow[t]{2}{*}{$\# 1 \mathrm{P}$} & \multirow[t]{2}{*}{ \#2 P } \\
\hline & Survival $n=34$ & Death $n=6$ & & & \\
\hline MIP-I $\beta$ & 38.97 (33.73) & $42.32(15.18)$ & $29.67(27.17)$ & 0.156 & 0.082 \\
\hline sCD40L & $358.7 \mid$ (III5.32) & 71.88 (42.82) & $187.68(305.94)$ & 0.179 & 0.213 \\
\hline TGF $\alpha$ & 3.66 (I.7I) & $3.20(0.00)$ & $3.32(0.70)$ & 0.280 & 0.940 \\
\hline $\mathrm{TNF} \alpha$ & $23.87(20.10)$ & $29.41(16.92)$ & $21.70(15.20)$ & 0.140 & 0.844 \\
\hline TNF $\beta$ & $4.06(3.34)$ & $3.47(0.65)$ & $6.65(14.25)$ & 0.663 & 0.714 \\
\hline VEGF & 79.62 (91.55) & 76.37 (79.77) & $83.45(103.23)$ & 0.761 & 0.995 \\
\hline
\end{tabular}

Notes: \#I, comparison between surviving and dead patients in the acute stage; \#2, comparison between surviving patients in the acute and subacute stages. The concentration of serum proteins is expressed in $\mathrm{pg} / \mathrm{mL}$.

proteins between the acute and subacute stage samples (Table 4).

\section{Correlation Analysis}

To attenuate the confounding effect of patient characteristics on the expression of circulating proteins. Pearson's correlation analysis was performed to measure the correlation between patient characteristics and differentially expressed protein targets. The correlations with significant expression of at least a moderate correlation coefficient $(r>0.4)$ are shown in Figure 3. Specific attention would be focused on those markers that only had correlation at the acute stage but not at the subacute stage, that is, $\mathrm{VWF}$ and AST $(r=0.46)$, G-CSF and HTN $(r=0.41)$, RTS $(r=-0.47)$, IL-6 and RR $(r=0.46)$, RTS $(r=-0.43)$, and IP-10 and BUN $(r=0.54)$, and $\mathrm{Cr}(r=$ $0.40)$. No correlation of these significantly expressed markers with gender, AIS in different body regions, and ISS was found both in the acute and subacute stages.

\section{Discussion}

The study revealed elevated levels of acute-phase proteins AGP and CRP but decreased levels of A2M, SAP, and vWF in the circulation of patients after severe trauma. In addition, the serum concentrations of cytokines G-CSF, IL-6, and IL-1RA were increased, and the levels of IL-4 and IP-10 decreased. However, there were no significant differences in the levels of checkpoint proteins in the circulation.

The expression of G-CSF and IL-6 following trauma has received increased research attention. G-CSF is a potent stimulator of hematopoietic mobilization in response to inflammatory stimuli and plays a pivotal
G - C S F

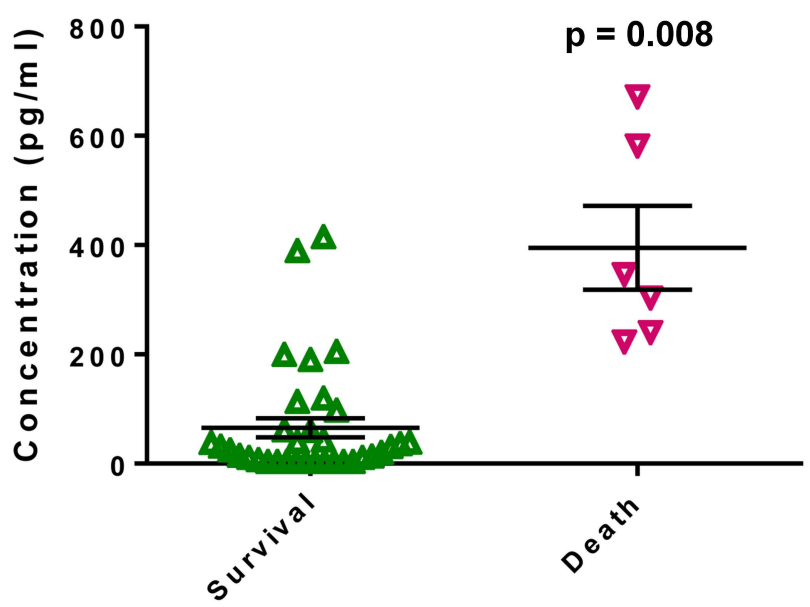

IL-6

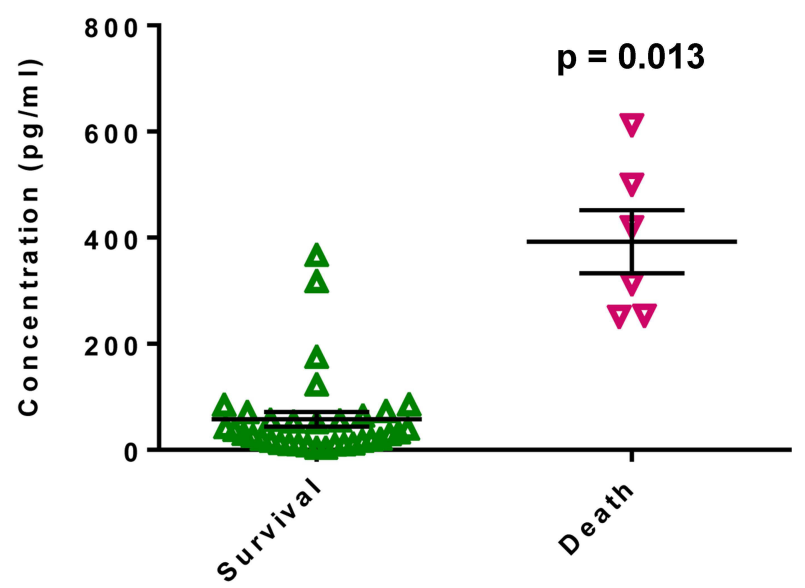

Figure 2 Circulating cytokines with significantly different expression in the acute-stage serum samples of the surviving and dead patients. 
Table 4 Expression of the Checkpoint Proteins in the Acute-Stage and Subacute-Stage Serum Samples

\begin{tabular}{|c|c|c|c|c|c|}
\hline \multirow[t]{2}{*}{ Variables } & \multicolumn{2}{|l|}{ Acute Stage } & \multirow{2}{*}{$\begin{array}{l}\text { Subacute Stage } \\
\text { Survival } n=34\end{array}$} & \multirow[t]{2}{*}{$\# \mid \mathbf{P}$} & \multirow[t]{2}{*}{ \#2 P } \\
\hline & Survival $n=34$ & Death $n=6$ & & & \\
\hline BTLA & I366 (I778) & 1666 (1749) & 1287 (I550) & 0.557 & 0.713 \\
\hline CD27 & $8116(12,323)$ & $10,150(5563)$ & $7601(18,287)$ & 0.078 & 0.312 \\
\hline CD28 & $9457(11,003)$ & $\mathrm{II}, 410(10,557)$ & 8557 (9425) & 0.449 & 0.917 \\
\hline CD40 & $884(1611)$ & $106 \mid(7 \mid 2)$ & IIIO (2609) & 0.092 & 0.339 \\
\hline CD80/B7-I & 265 (337) & $344(4 \mid 2)$ & $249(288)$ & 0.691 & 0.504 \\
\hline CD86/B7-2 & $1719(2120)$ & 2291 (2498) & 1919 (1959) & 0.609 & 0.194 \\
\hline CTLA-4 & $153(263)$ & 207 (308) & $204(258)$ & 0.746 & 0.422 \\
\hline GITR & 231 (458) & $283(516)$ & 291 (407) & 0.835 & 0.086 \\
\hline GITRL & $580(68 I)$ & 735 (835) & $713(664)$ & 0.880 & 0.087 \\
\hline HVEM & 3567 (5।85) & $5004(3528)$ & 3277 (5257) & 0.072 & 0.937 \\
\hline ICOS & II84 (1652) & I375 (1642) & II82 (1364) & 0.438 & 0.139 \\
\hline LAG-3 & $34,676(34,291)$ & $45,725(39,062)$ & $32,732(26,71 I)$ & 0.719 & 0.544 \\
\hline PD-I & I 474 (2|78) & 1893 (2307) & $1749(2103)$ & 0.460 & 0.083 \\
\hline PD-LI & |4| (243) & 176 (258) & $166(225)$ & 0.472 & 0.054 \\
\hline TIM-3 & $6265(7223)$ & $9086(8117)$ & $567(5442)$ & 0.099 & 0.893 \\
\hline TLR-2 & 2420 (2659) & $2772(27 \mid 3)$ & $2227(244 I)$ & 0.583 & 0.917 \\
\hline
\end{tabular}

Notes: \#I, comparison between surviving and dead patients in the acute stage; \#2, comparison between surviving patients in the acute and subacute stages. The concentration of serum proteins is expressed in $\mathrm{pg} / \mathrm{mL}$.

role in the expansion and differentiation of neutrophils in the bone marrow and their subsequent release into the blood circulation. ${ }^{28}$ A significant positive correlation between injury severity and circulating levels of G-CSF was found in patients with trauma. ${ }^{7,29,30}$ Patients in shock would have a 75-fold increase in G-CSF levels compared to those in the control group. ${ }^{31}$ Trauma patients with burns or sepsis have a similar increase in circulating G-CSF levels. ${ }^{29,32}$ Elevated G-CSF levels result in early and sustained mobilization of hematopoietic progenitor cells into the periphery in patients with severe trauma. ${ }^{31}$ Therefore, G-CSF is likely to respond to abnormal erythropoiesis after trauma, ${ }^{31}$ in which the anemic state persists in the bone marrow and lasts for at least two weeks. $^{33}$

In addition, G-CSF is required for bacterial clearance. During acute infection, G-CSF is detected in the blood, along with the release of proinflammatory cytokines. ${ }^{34}$ G-CSF is released by monocytes and macrophages upon activation by endotoxins during infection. ${ }^{35}$ Higher G-CSF levels were associated with a three-fold greater incidence of acquired pneumonia and sepsis in hospitals. ${ }^{31}$ Likewise, in this study, the serum concentrations of G-CSF and IL-6 in patients who died were significantly higher than those in the surviving patients. Notably, depletion of endogenous G-CSF in vivo would make the animal more susceptible to experimental peritonitis than the control ${ }^{36}$ and lack of G-CSF was associated with a higher rate of sepsis. ${ }^{37}$ A clinical trial has shown that G-CSF treatment in patients with septic shock is associated with a dramatic improvement in patient survival. ${ }^{38}$ In brief, the level of G-CSF correlated with the severity of the injury in trauma patients, and the increased G-CSF acts to encounter stress with the mobilization of hematopoietic progenitor cells into the periphery. Higher morbidity and mortality may be encountered if G-CSF activation is blocked.

After trauma, prolonged and excessive elevations of circulating IL-6 levels have been reported and are highly associated with complications and mortality in patients. $^{39,40}$ IL-6 is primarily synthesized by bone 


\section{Acute stage}

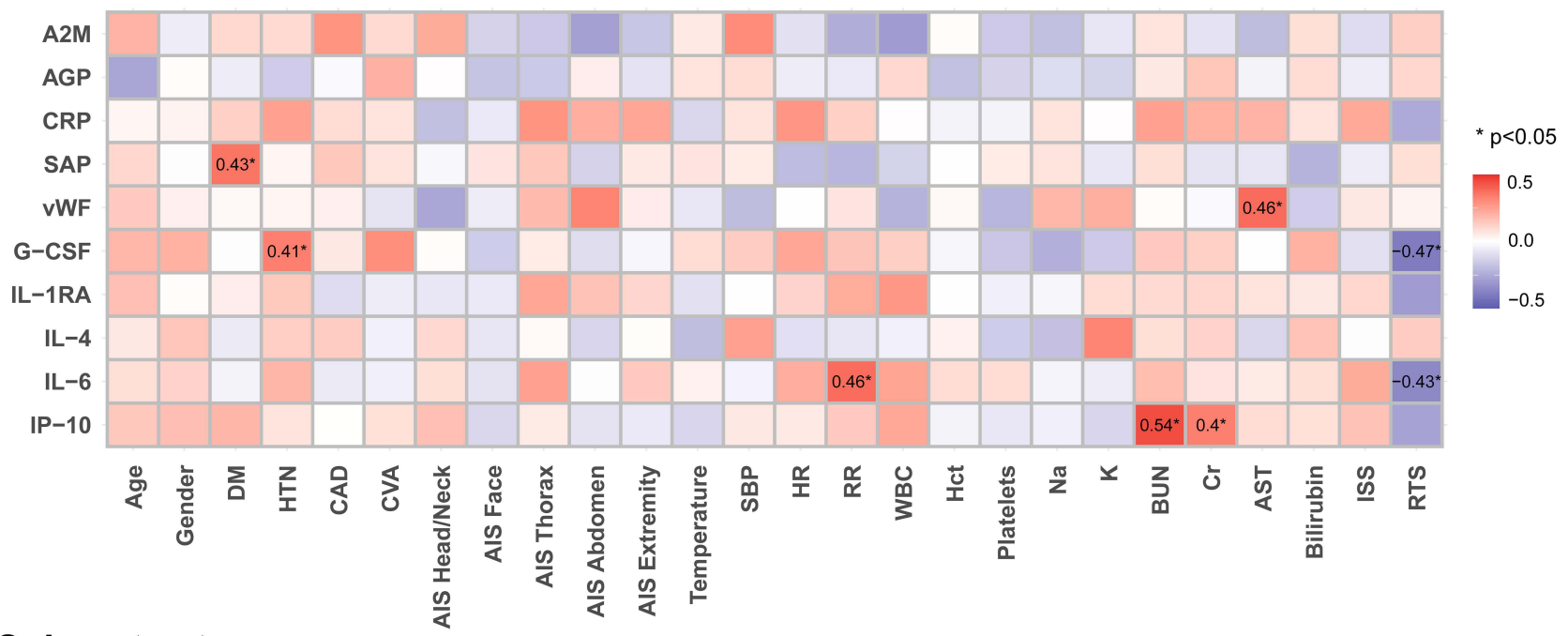

\section{Subacute stage}

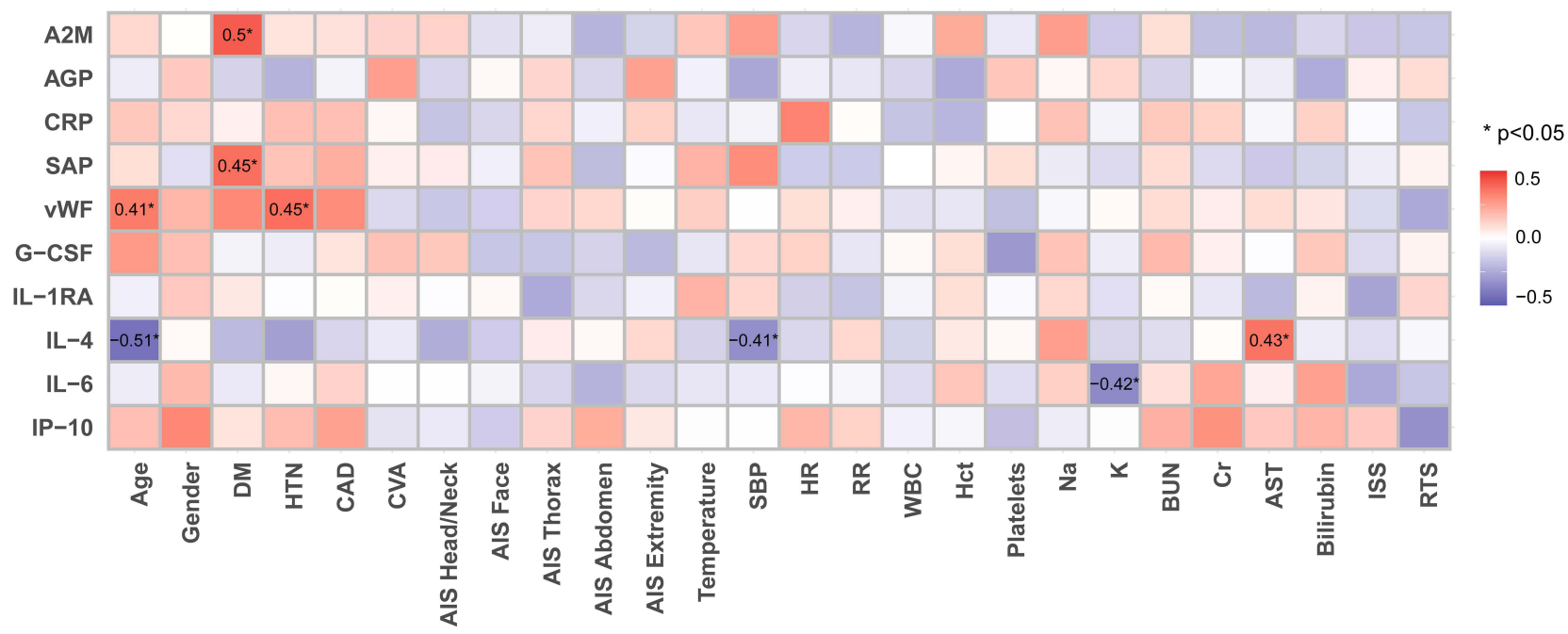

Figure 3 Correlation of the differentially expressed circulating proteins with patient characteristics in the first (acute stage) and second (subacute stage) measurement of the samples.

marrow stromal fibroblasts ${ }^{33,41}$ which also participate in cytokine regulation. ${ }^{42,43}$ Hemorrhagic shock can induce elevation of IL- 6 and TNF- $\alpha$, both of which in turn mediate the endogenous production of G-CSF. ${ }^{44}$ After traumatic brain injury, IL-6 levels are elevated within hours of injury $^{5,45}$ and up to 2.4-fold in three hours, 3.7-fold in 24 hours, and 7.9-fold on the fifth day compared to the control subjects. ${ }^{46}$ IL-6 stimulates B cells to produce antibodies and inhibits insulin action through modification of insulin receptor signaling, thus increasing hypermetabolic and insulin resistance in the liver and skeletal muscle. ${ }^{47}$ IL-6 is also responsible for the induction of acute-phase inflammatory responses via stimulation of the liver to produce acute-phase proteins. ${ }^{47} \mathrm{~A}$ higher serum level of
IL-6 is associated with the development of post-traumatic stress symptoms following injury. ${ }^{48,49}$ In patients with severe injuries, this increase in IL-6 may persist longer. ${ }^{50}$ In a study of 472 blunt trauma survivors, IL-6 production was affected over seven days post-injury by MCP-1, MIG, and IP-10 in patients with severe ISS, MCP-1, and MIG in patients with moderate ISS, and MIG alone in patients with mild ISS. ${ }^{39}$ Similarly, higher IL-6 plasma levels in trauma patients tend to lead to complications or death. ${ }^{51}$

CRP is a sensitive marker for detecting the acute phase of inflammation. It has been reported that after trauma, blood CRP levels are markedly increased during all periods of observation. ${ }^{46}$ In this study, the elevation of CRP was approximately three-fold higher in the serum of the 
acute stage than in the subacute stage. A major function of CRP is to bind phosphocholine and thus recognize phospholipid constituents of damaged cells and that of foreign pathogens. $^{7}$ The formation of these protein-ligand complexes would then be removed by mononuclear macrophages. Other pro-inflammatory effects of CRP include the induction of inflammatory cytokines and tissue factors in monocytes. ${ }^{1}$ CRP and SAP belong to the pentraxin family of proteins and are involved in the activation of the complement cascade. ${ }^{52} \mathrm{SAP}$ is a physiological and functional counterpart of CRP in humans. ${ }^{53}$ During systemic inflammation, substantial induction of serum SAP was observed.$^{53} \mathrm{SAP}$ is also released into the circulation in correlation with its antimicrobial and anti-inflammatory activities. $^{54,55}$ The primary pathophysiological function of SAP is to modulate nuclear antigens that are exposed to the extracellular environment due to apoptosis or necrosis. ${ }^{56}$

In addition to CRP and SAP, three other acute-phase proteins (AGP, A2M, and vWF) were dysregulated in the acute stage after traumatic injury. AGP levels in acute trauma patients have been shown to exceed normal levels. ${ }^{57}$ Administration of AGP was reported to significantly reduce neutrophil accumulation, lipid peroxidation, and edema formation during resuscitation against traumahemorrhagic shock. ${ }^{58}$ Decreased $\mathrm{A} 2 \mathrm{M}$ was noted due to hemodilution by fluid treatment, first extravasation and accumulation of proteins at the wound site, and altered hepatic protein production. ${ }^{59}$ The severity of trauma and the extent of wound tissue induces a parallel decrease in both albumin and A2M. ${ }^{59}$ In addition, vWF plays an important role in both hemostasis and thrombosis. A decreased plasma level of vWF points to a bleeding disorder. ${ }^{60}$

In this study, the dysregulated cytokines included increased levels of IL-1RA and decreased levels of IL-4 and IP-10. IL-1 is an important mediator of inflammation and cardiovascular disease, ${ }^{43,61,62}$ and its activity is modulated by IL-1RA, which has been reported to increase in the plasma one day following trauma. ${ }^{63}$ Endogenous IL-1RA suppresses occlusive vascular responses to injuries, such as atherosclerosis and restenosis. ${ }^{64}$ The absence of IL-1RA promotes neointimal formation after injury in mice. Furthermore, it has been reported that IL-4 levels are significantly lower in orthopedic trauma patients than in controls. ${ }^{40}$ IL-4 has been suggested to be an antiinflammatory cytokine and works with other regulatory cytokines such as TGF- $\beta$ and IL-10 to reduce the severity of the inflammatory reaction. ${ }^{13}$ In addition, IP-10 has been reported to be suppressed during injury. ${ }^{65}$ Levels of IP-10 in the circulation were significantly lower in human blunt trauma nonsurvivors than in survivors. ${ }^{66}$ The signaling mechanism that controls IP-10 expression also plays an important role in injury-induced inflammation. ${ }^{66}$

Considering that the patient characteristics, such as age, sex, pre-existing comorbidities, and injured regions, may present a confounder's effect on the expression of circulating proteins, ${ }^{67}$ correlation analysis was performed to inspect the relationships of the significantly expressed protein targets and various patient characteristics. The results revealed that there was no correlation of these significantly expressed proteins with gender, AIS in different body regions, and ISS both in the acute and subacute stages. Interestingly, in the acute stage, the expression of some circulating proteins is correlated with the underlying conditions of the patients, such as the correlation between vWF and liver disease, ${ }^{68}$ G-CSF and HTN, ${ }^{69}$ IL-6 and dyspnea, ${ }^{70}$ as well as IP-10 and acute kidney injury ${ }^{71}$ has been recognized in the literature. Moreover, because the calculation of RTS was based on GCS, SBP, and RR [27], the relationship between RTS and G-CSF, which was correlated with HTN, as well as IL-6, which was correlated with RR, can be recognized.

Cytokines and cytokine receptors operate both as a cascade and as a network to stimulate the production of acute-phase proteins. ${ }^{1}$ The effects of cytokines on target cells may be inhibited or enhanced by other cytokines, hormones, cytokine-receptor antagonists, and circulating receptors. ${ }^{7}$ In addition, these cells are most likely exposed and are influenced by a combination of mediators, regardless of acute-phase proteins or cytokines. The identified dysregulated proteins in this study may serve as potential therapeutic targets or biomarkers for treating patients with severe trauma. However, the related biological functions of these dysregulated factors require further investigation to validate their functions. Furthermore, the measurement of these identified significantly dysregulated circulating proteins in a large scale numbers of cohort of patients with severe trauma and patients with ISS scores less than 16 would provide more valuable information for exploring the role of these proteins. In this study, there were no significant differences in the expression of checkpoint proteins in the circulation. Immune checkpoints are a normal part of the immune system to prevent an overreactive immune response that destroys healthy cells. ${ }^{72}$ This study did not identify evidence of involvement of the surveillance system of immune checkpoints to combat the immune response of patients who sustained severe 
trauma. However, further measuring of the expression of immune checkpoint proteins in T cells or immune cells of patients is encouraged.

This study has some limitations. First, conditions such as resuscitation, damage control, surgical intervention, and even the use of drugs such as beta-blockers, antihypertensive drugs, and hypoglycemic drugs may lead to a bias. Second, the circulating proteins were dynamic in nature, and the conclusions drawn from a single measurement or two measurements may differ from those drawn from multiple measurements averaged over time. Further, the study population was relatively small to depict a complex network condition of these circulating proteins; thus, it can only serve as a pilot study. Finally, the population included in this study was limited to a single urban trauma center. However, the identified dysregulated proteins in this study may serve as potential therapeutic targets or biomarkers for treating patients with severe trauma, although the related biological functions of these dysregulated factors require further investigation to validate their function. Furthermore, the measurement of these identified significantly dysregulated circulating proteins in cohorts consisting of a large number of patients with severe trauma and patients with ISS scores less than 16 would provide more valuable information for exploring the role of these proteins.

\section{Conclusion}

The study identified that the levels of acute-phase proteins, such as AGP and CRP, and cytokines, such as G-CSF, IL6 , and IL-1RA, were elevated in the circulation after severe trauma, while the levels of acute-phase proteins, such as A2M, SAP, and vWF, and cytokines, including IL4 and IP-10, were reduced. These identified dysregulated proteins may serve as potential therapeutic targets or biomarkers for treating patients with severe trauma.

\section{Abbreviations}

AGP, alpha-1-acid glycoprotein; AIS, abbreviated injury scale; AST, aspartate aminotransferase; A2M, alpha2-macroglobulin; BUN, blood urine nitrogen; $\mathrm{Cr}$, creatinine; CRP, C-reactive protein; DM, diabetes mellitus; GCS, Glasgow Coma Scale; G-CSF, granulocyte colonystimulating factor; Hct, hematocrit; HR, heart rate; HTN, hypertension; ICU, intensive care unit; IL, interleukin; IL1RA, interleukin-1 receptor antagonist; IP-10, interferon gamma-induced protein 10; ISS, injury severity score; $\mathrm{K}$, potassium; Na, sodium; PD-L1, programmed cell death ligand-1; SBP, systolic blood pressure; RR, respiratory rate; RTS, Revised Trauma Score; SAP, Serum Amyloid P; TRISS, Trauma and Injury Severity Score; WBC, white blood cell; vWF, von Willebrand Factor.

\section{Ethics Approval and Informed Consent}

The study protocol was approved by the Institutional Review Board of Chang Gung Memorial Hospital (ref: 201701425B0) under the ethical guidelines of the 1975 Declaration of Helsinki. Written informed consent was obtained from all subjects involved in the study.

\section{Acknowledgments}

We are grateful for the support provided by the Center for Composite Tissue Allotransplantation, Chang Gung Memorial Hospital, Linkou and Biostatistics Center, Kaohsiung Chang Gung Memorial Hospital.

\section{Funding}

This work was supported by the Chang Gung Memorial Hospital (CMRPG8L0191 to Ching-Hua Hsieh).

\section{Disclosure}

The authors report no conflicts of interest in this work.

\section{References}

1. Gabay C, Kushner I, Epstein FH. Acute-phase proteins and other systemic responses to inflammation. $N$ Engl J Med. 1999;340 (6):448-454. doi:10.1056/NEJM199902113400607

2. Gauldie J, Lamontagne L, Stadnyk A. Acute phase response in infectious disease. Surv Synth Pathol Res. 1985;4(2):126-151.

3. Renckens R, van Westerloo DJ, Roelofs JJTH, et al. Acute phase response impairs host defense against Pseudomonas aeruginosa pneumonia in mice. Crit Care Med. 2008;36(2):580-587. doi:10.1097/01. CCM.0B013E3181620652

4. Renckens R, Roelofs J, Knapp S, de Vos AF, Florquin S, van der Poll T. The acute-phase response and serum amyloid a inhibit the inflammatory response to Acinetobacter baumannii Pneumonia. J Infect Dis. 2006;193(2):187-195. doi:10.1086/498876

5. Di Battista AP, Rhind SG, Hutchison MG, et al. Inflammatory cytokine and chemokine profiles are associated with patient outcome and the hyperadrenergic state following acute brain injury. J Neuroinflammation. 2016;13:40. doi:10.1186/s12974-016-0500-3

6. Catania A, Lonati C, Sordi A, Gatti S. Detrimental consequences of brain injury on peripheral cells. Brain Behav Immun. 2009;23 (7):877-884. doi:10.1016/j.bbi.2009.04.006

7. Miller ES, Loftus TJ, Kannan KB, Plazas JM, Efron PA, Mohr AM. Systemic regulation of bone marrow stromal cytokines after severe trauma. J Surg Res. 2019;243:220-228. doi:10.1016/j.jss.2019.05.033

8. Limoge M, Safina A, Beattie A, Kapus L, Truskinovsky AM, Bakin AV. Tumor-fibroblast interactions stimulate tumor vascularization by enhancing cytokine-driven production of MMP9 by tumor cells. Oncotarget. 2017;8(22):35592-35608. doi:10.18632/ oncotarget. 16022 
9. Bible LE, Pasupuleti LV, Alzate WD, et al. Early propranolol administration to severely injured patients can improve bone marrow dysfunction. J Trauma Acute Care Surg. 2014;77(1):54-60. doi:10.1097/TA.0000000000000264

10. Alamo IG, Kannan KB, Loftus TJ, Ramos H, Efron PA, Mohr AM. Severe trauma and chronic stress activates extramedullary erythropoiesis. J Trauma Acute Care Surg. 2017;83(1):144-150. doi:10.1097/TA.0000000000001537

11. Millar JK, Kannan KB, Loftus TJ, et al. Persistent injury-associated anemia: the role of the bone marrow microenvironment. J Surg Res. 2017;214:240-246. doi:10.1016/j.jss.2017.03.018

12. Sears BW, Stover MD, Callaci J. Pathoanatomy and clinical correlates of the immunoinflammatory response following orthopaedic trauma. J Am Acad Orthop Surg. 2009;17(4):255-265. doi:10.5435/ 00124635-200904000-00006

13. Roberts CS, Pape HC, Jones AL, Malkani AL, Rodriguez JL, Giannoudis PV. Damage control orthopaedics: evolving concepts in the treatment of patients who have sustained orthopaedic trauma. Instr Course Lect. 2005;54:447-462.

14. Wigmore SJ, Fearon KC, Maingay JP, Lai PB, Ross JA. Interleukin-8 can mediate acute-phase protein production by isolated human hepatocytes. Am J Physiol. 1997;273(4):E720-E726.

15. Wakeley ME, Gray CC, Monaghan SF, Heffernan DS, Ayala A. Check point inhibitors and their role in immunosuppression in sepsis. Crit Care Clin. 2020;36(1):69-88. doi:10.1016/j. ccc.2019.08.006

16. Cai G, Freeman GJ. The CD160, BTLA, LIGHT/HVEM pathway: a bidirectional switch regulating T-cell activation. Immunol Rev. 2009;229(1):244-258. doi:10.1111/j.1600-065X.2009.00783.x

17. Patil NK, Luan L, Bohannon JK, Hernandez A, Guo Y, Sherwood ER. Frontline science: anti-PD-L1 protects against infection with common bacterial pathogens after burn injury. J Leukoc Biol. 2018;103(1):23-33. doi:10.1002/JLB.5HI0917-360R

18. Chen Q, Xu L, Du T, et al. Enhanced expression of PD-L1 on microglia after surgical brain injury exerts self-protection from inflammation and promotes neurological repair. Neurochem Res. 2019;44(11):2470-2481. doi:10.1007/s11064-019-02864-8

19. Yang W, Liu Y, Liu B, et al. Treatment of surgical brain injury by immune tolerance induced by intrathymic and hepatic portal vein injection of brain antigens. Sci Rep. 2016;6(1):32030. doi:10.1038/ srep32030

20. Jeschke MG, Gauglitz GG, Finnerty CC, Kraft R, Mlcak RP, Herndon DN. Survivors versus nonsurvivors postburn: differences in inflammatory and hypermetabolic trajectories. Ann Surg. 2014;259(4):814-823. doi:10.1097/SLA.0b013e31828dfbf1

21. Hsu SY, Wu SC, Rau CS, et al. Impact of adapting the Abbreviated Injury Scale (AIS)-2005 from AIS-1998 on injury severity scores and clinical outcome. Int J Environ Res Public Health. 2019;16:24. doi:10.3390/ijerph 16245033

22. Stewart KE, Cowan LD, Thompson DM. Changing to AIS 2005 and agreement of injury severity scores in a trauma registry with scores based on manual chart review. Injury. 2011;42(9):934-939. doi:10.1016/j.injury.2010.05.033

23. Newgard $\mathrm{CD}, \mathrm{Fu} \mathrm{R}$, Lerner EB, et al. Deaths and high-risk trauma patients missed by standard trauma data sources. J Trauma Acute Care Surg. 2017;83(3):427-437. doi:10.1097/ TA.0000000000001616

24. Hsieh CH, Hsu SY, Hsieh HY, Chen YC. Differences between the sexes in motorcycle-related injuries and fatalities at a Taiwanese level I trauma center. Biomed J. 2017;40(2):113-120. doi:10.1016/j. bj.2016.10.005

25. Hsieh CH, Liu HT, Hsu SY, Hsieh HY, Chen YC. Motorcycle-related hospitalizations of the elderly. Biomed J. 2017;40(2):121-128. doi:10.1016/j.bj.2016.10.006
26. Hsieh CH, Chen YC, Hsu SY, Hsieh HY, Chien PC. Defining polytrauma by abbreviated injury scale $>/=3$ for a least two body regions is insufficient in terms of short-term outcome: a cross-sectional study at a level I trauma center. Biomed J. 2018;41(5):321-327. doi:10.1016/j.bj.2018.08.007

27. Champion HR, Sacco WJ, Copes WS, Gann DS, Gennarelli TA, Flanagan ME. A revision of the trauma score. J Trauma. 1989;29 (5):623-629. doi:10.1097/00005373-198905000-00017

28. Fang H, Jiang W, Cheng J, et al. Balancing innate immunity and inflammatory state via modulation of neutrophil function: a novel strategy to fight sepsis. J Immunol Res. 2015;2015:187048. doi:10.1155/2015/187048

29. Tanaka H, Ishikawa K, Nishino M, Shimazu T, Yoshioka T. Changes in granulocyte colony-stimulating factor concentration in patients with trauma and sepsis. J Trauma. 1996;40(5):718-725; discussion 725-716. doi:10.1097/00005373-199605000-00006

30. Korkmaz S, Altuntas F. What is the role of biosimilar G-CSF agents in hematopoietic stem cell mobilization at present? Transfus Apher Sci. 2017;56(6):795-799.

31. Cook KM, Sifri ZC, Baranski GM, Mohr AM, Livingston DH. The role of plasma granulocyte colony stimulating factor and bone marrow dysfunction after severe trauma. J Am Coll Surg. 2013;216 (1):57-64. doi:10.1016/j.jamcollsurg.2012.08.028

32. Presneill JJ, Waring PM, Layton JE, et al. Plasma granulocyte colony-stimulating factor and granulocyte-macrophage colony-stimulating factor levels in critical illness including sepsis and septic shock: relation to disease severity, multiple organ dysfunction, and mortality. Crit Care Med. 2000;28(7):2344-2354. doi:10.1097/00003246-200007000-00028

33. Livingston DH, Anjaria D, Wu J, et al. Bone marrow failure following severe injury in humans. Ann Surg. 2003;238(5):748-753. doi:10.1097/01.sla.0000094441.38807.09

34. Cebon J, Layton JE, Maher D, Morstyn G. Endogenous haemopoietic growth factors in neutropenia and infection. Br J Haematol. 1994;86 (2):265-274. doi:10.1111/j.1365-2141.1994.tb04725.x

35. Root RK, Dale DC. Granulocyte colony-stimulating factor and granulocyte-macrophage colony-stimulating factor: comparisons and potential for use in the treatment of infections in nonneutropenic patients. J Infect Dis. 1999;179(Suppl 2):S342-S352. doi:10.1086/ 513857

36. Lieschke GJ, Grail D, Hodgson G, et al. Mice lacking granulocyte colony-stimulating factor have chronic neutropenia, granulocyte and macrophage progenitor cell deficiency, and impaired neutrophil mobilization. Blood. 1994;84(6):1737-1746. doi:10.1182/blood. V84.6.1737.1737

37. Hammond WP, Csiba E, Canin A, et al. Chronic neutropenia. A new canine model induced by human granulocyte colony-stimulating factor. J Clin Invest. 1991;87(2):704-710. doi:10.1172/JCI115049

38. Stephens DP, Fisher DA, Currie BJ. An audit of the use of granulocyte colony-stimulating factor in septic shock. Intern Med J. 2002;32 (4):143-148. doi:10.1046/j.1445-5994.2002.00195.x

39. Almahmoud K, Namas RA, Abdul-Malak O, et al. Impact of injury severity on dynamic inflammation networks following blunt trauma. Shock. 2015;44(2):101-109. doi:10.1097/SHK.0000000000000395

40. Volpin G, Cohen M, Assaf M, Meir T, Katz R, Pollack S. Cytokine levels (IL-4, IL-6, IL-8 and TGF $\beta$ ) as potential biomarkers of systemic inflammatory response in trauma patients. Int Orthop. 2014;38 (6):1303-1309. doi:10.1007/s00264-013-2261-2

41. Wu JC, Livingston DH, Hauser CJ, Deitch EA, Rameshwar P. Trauma inhibits erythroid burst-forming unit and granulocyte-monocyte colony-forming unit growth through the production of TGF-beta1 by bone marrow stroma. Ann Surg. 2001;234 (2):224-232. doi:10.1097/00000658-200108000-00013 
42. Ulrich-Merzenich G, Hartbrod F, Kelber O, Müller J, Koptina A, Zeitler H. Salicylate-based phytopharmaceuticals induce adaptive cytokine and chemokine network responses in human fibroblast cultures. Phytomedicine. 2017;34:202-211. doi:10.1016/j. phymed.2017.08.002

43. Conti P, Ronconi G, Caraffa A, et al. Induction of pro-inflammatory cytokines (IL-1 and IL-6) and lung inflammation by Coronavirus-19 (COVI-19 or SARS-CoV-2): anti-inflammatory strategies. J Biol Regul Homeost Agents. 2020;34(2):327-331.

44. Kumar M, Bhoi S. Impaired hematopoietic progenitor cells in trauma hemorrhagic shock. J Clin Orthop Trauma. 2016;7(4):282-285. doi:10.1016/j.jcot.2016.05.013

45. Santarsieri M, Kumar RG, Kochanek PM, Berga S, Wagner AK. Variable neuroendocrine-immune dysfunction in individuals with unfavorable outcome after severe traumatic brain injury. Brain Behav Immun. 2015;45:15-27. doi:10.1016/j.bbi.2014.09.003

46. Ziablitsev SV, Pishchulina SV, Kolesnikova SV, Boris RN. Systemic effects of unspecific inflammatory reaction at traumatic brain injury. Fiziol Zh. 2016;62(1):68-73. doi:10.15407/fz62.01.068

47. Del Aguila LF, Claffey KP, Kirwan JP. TNF-alpha impairs insulin signaling and insulin stimulation of glucose uptake in $\mathrm{C} 2 \mathrm{C} 12$ muscle cells. Am J Physiol. 1999;276(5):E849-E855.

48. Cohen M, Meir T, Klein E, Volpin G, Assaf M, Pollack S. Cytokine levels as potential biomarkers for predicting the development of posttraumatic stress symptoms in casualties of accidents. Int J Psychiatry Med. 2011;42(2):117-131. doi:10.2190/PM.42.2.b

49. Pervanidou P, Kolaitis G, Charitaki S, et al. Elevated morning serum interleukin (IL)-6 or evening salivary cortisol concentrations predict posttraumatic stress disorder in children and adolescents six months after a motor vehicle accident. Psychoneuroendocrinology. 2007;32 (8-10):991-999. doi:10.1016/j.psyneuen.2007.07.001

50. Pape HC, Rixen D, Morley J, et al. Impact of the method of initial stabilization for femoral shaft fractures in patients with multiple injuries at risk for complications (borderline patients). Ann Surg. 2007;246(3):491-499; discussion 499-501. doi:10.1097/ SLA.0b013e3181485750

51. Qiao Z, Wang W, Yin L, et al. Using IL-6 concentrations in the first $24 \mathrm{~h}$ following trauma to predict immunological complications and mortality in trauma patients: a meta-analysis. Eur J Trauma Emerg Surg. 2018;44(5):679-687. doi:10.1007/s00068-017-0880-9

52. Bottazzi B, Doni A, Garlanda C, Mantovani A. An integrated view of humoral innate immunity: pentraxins as a paradigm. Annu Rev Immunol. 2010;28:157-183. doi:10.1146/annurev-immunol-030409101305

53. Cho K, Pham TN, Crivello SD, Jeong J, Green TL, Greenhalgh DG. Involvement of CD14 and toll-like receptor 4 in the acute phase response of serum amyloid A proteins and serum amyloid P component in the liver after burn injury. Shock. 2004;21 (2):144-150. doi:10.1097/01.shk.0000108398.56565.ae

54. De Buck M, Gouwy M, Wang JM, et al. Structure and expression of different Serum Amyloid A (SAA) variants and their concentration-dependent functions during host insults. Curr Med Chem. 2016;23(17):1725-1755. doi:10.2174/0929867323666 160418114600

55. Sack GH Jr. Serum amyloid A - a review. Mol Med. 2018;24(1):46.

56. Noursadeghi M, Bickerstaff MC, Gallimore JR, Herbert J, Cohen J, Pepys MB. Role of serum amyloid P component in bacterial infection: protection of the host or protection of the pathogen. Proc Natl Acad Sci U S A. 2000;97(26):14584-14589. doi:10.1073/ pnas.97.26.14584
57. Christie J, Markowsky SJ, Valdes C. Acute trauma alters morphine clearance. J Trauma. 1995;39(4):749-752. doi:10.1097/00005373199510000-00026

58. Kuebler JF, Toth B, Yokoyama Y, Bland KI, Rue LW 3rd, Chaudry IH. Alpha1-acid-glycoprotein protects against trauma-hemorrhagic shock. J Surg Res. 2004;119(1):21-28. doi:10.1016/j.jss.2003.07.007

59. Lasson A, Berling R, Göransson J, Ohlsson K. Alpha-2-macroglobulin decreases parallel to albumin and haemoglobin after elective surgery. Scand J Clin Lab Invest. 1991;51(3):225-233. doi:10.3109/ 00365519109091609

60. Shahidi M. Thrombosis and von Willebrand factor. $A d v$ Exp Med Biol. 2017;906:285-306.

61. Gelardi M, La Mantia I, Drago L, et al. A probiotic mixture in patients with upper respiratory diseases: the point of view of the otorhinolaringologist. J Biol Regul Homeost Agents. 2020;34 (6Suppl. 1):5-10.

62. Conti P, Caraffa A, Gallenga CE, et al. Coronavirus-19 (SARS-CoV2) induces acute severe lung inflammation via IL-1 causing cytokine storm in COVID-19: a promising inhibitory strategy. J Biol Regul Homeost Agents. 2020;34(6):1971-1975.

63. Cahill LA, Guo F, Nguyen J, et al. Circulating factors in trauma plasma activate specific human immune cell subsets. Injury. 2020;51 (4):819-829. doi:10.1016/j.injury.2020.03.009

64. Isoda K, Shiigai M, Ishigami N, et al. Deficiency of interleukin-1 receptor antagonist promotes neointimal formation after injury. Circulation. 2003;108(5):516-518. doi:10.1161/01. CIR.0000085567.18648.21

65. Cahill LA, Joughin BA, Kwon WY, et al. Multiplexed plasma immune mediator signatures can differentiate sepsis from NonInfective SIRS: American Surgical Association 2020 annual meeting paper. Ann Surg. 2020;272(4):604-610. doi:10.1097/ SLA.0000000000004379

66. Wang J, Vodovotz Y, Fan L, et al. Injury-induced MRP8/MRP14 stimulates IP-10/CXCL10 in monocytes/macrophages. FASEB $J$. 2015;29(1):250-262. doi:10.1096/fj.14-255992

67. Conti P, Younes A. Coronavirus COV-19/SARS-CoV-2 affects women less than men: clinical response to viral infection. $J$ Biol Regul Homeost Agents. 2020;34(2):339-343.

68. Eidelberg A, Kirubakaran R, Nair SC, Eapen CE, Elias E, Goel A. Systematic review: role of elevated plasma von-Willebrand factor as predictor of mortality in patients with chronic liver disease. Eur J Gastroenterol Hepatol. 2019;31(10):1184-1191. doi:10.1097/ MEG.0000000000001491

69. Parissis JT, Korovesis S, Giazitzoglou E, Kalivas P, Katritsis D. Plasma profiles of peripheral monocyte-related inflammatory markers in patients with arterial hypertension. Correlations with plasma endothelin-1. Int J Cardiol. 2002;83(1):13-21. doi:10.1016/S01675273(02)00021-9

70. Rincon M, Irvin CG. Role of IL-6 in asthma and other inflammatory pulmonary diseases. Int $J$ Biol Sci. 2012;8(9):1281-1290. doi:10.7150/ijbs.4874

71. Amaral Pedroso L, Nobre V, Dias Carneiro de Almeida C, et al. Acute kidney injury biomarkers in the critically ill. Clin Chim Acta. 2020;508:170-178. doi:10.1016/j.cca.2020.05.024

72. Palma Dos Reis AF, Hennig I, Wilcock A. Immune checkpoint inhibitors: current status. BMJ Support Palliat Care. 2021. doi:10.1136/bmjspcare-2021-002954 


\section{Publish your work in this journal}

The Journal of Inflammation Research is an international, peerreviewed open-access journal that welcomes laboratory and clinical findings on the molecular basis, cell biology and pharmacology of inflammation including original research, reviews, symposium reports, hypothesis formation and commentaries on: acute/chronic inflammation; mediators of inflammation; cellular processes; molecular mechanisms; pharmacology and novel anti-inflammatory drugs; clinical conditions involving inflammation. The manuscript management system is completely online and includes a very quick and fair peerreview system. Visit http://www.dovepress.com/testimonials.php to read real quotes from published authors.

Submit your manuscript here: https://www.dovepress.com/journal-of-inflammation-research-journal 